\title{
A Brief Analysis of the Overseas Investment Strategy of Chinese State-owned Enterprises
}

\author{
Jiawei Zhang, Jing Li \\ Jack Austin Centre for Asia Pacific Studies, Beedie School of Business, SFU, Canada
}

\begin{abstract}
Keywords: China's state-owned enterprises, Company law, Overseas investment, Strategic motives, The integration of world trade
\end{abstract}

\begin{abstract}
By comparing various kinds of economic data of China's state-owned enterprises after the implementation the "company law" in the special view of the promulgation and implementation and the four times modification of "company law" after China's reform and opening up , The article elaborates the essential features of China's state-owned enterprises and the powerful economic incentives of overseas investment strategy, calling for overseas host countries and overseas groups to reduce political concerns, implementing win-win cooperation strategy, and building a harmonious and competitive overseas investment markets that full of energy around the world together.
\end{abstract}

\section{Introduction}

In recent years, with the rapid development of China's economy and the increasing of comprehensive national strength, a large number of Chinese companies going abroad and participate in international competition,becoming a new force that can not be neglected in the global economy market, focus of oversea on investment enthusiasm of China has been heating up. Chinese state-owned enterprises as the main investment strength, whose special system of state-owned enterprises has become the hot topic of overseas, holding mixed reviews for overseas investment strategy of China's state-owned enterprises. The writer tries to make a brief analysis of the overseas investment strategy of Chinese state owned enterprises in the special view of the promulgation and implementation and the four times modification of "company law" after China's reform and opening up

\section{The promulgation and implementation and the four-time modification of China's "company law" witnessed the progress of the state-owned system reform of China's state-owned enterprises for 20 years}

The promulgation and implementation China's "company law" in1994 has the extremely important significance on the reform of state-owned enterprises and the development history 。 "Company law" straighten out the relationship between government and enterprises eliminates government's administrative intervention in the form of legal rule for the first time, explicitly proposing to establish the modern enterprise system , which will be adapted to the requirements of the market economy with clarified ownership, distinct rights and responsibilities, separate government functions from enterprise management and scientific management, and clearly putting forward to make state-owned enterprises become an independent legal entity and main body of market competition.

Unfortunately, due to the planned economy mode and framework system of the tailored state-owned enterprise reform remain there, although the company law has been enacted, but in the actual production and operation activities, autonomy of the state-owned enterprises is restrained, lacking the spirit of freedom of contract, confining the independent development, free competition and self management of which state-owned enterprises as the main body of the market. In 1999 and 2004, China's National People's Congress standing committee makes two times "little change" of the "company law", but does not play a substantial role to the development of state-owned enterprises.

The Revised "company law" in 2005, aiming at the disadvantages of corporate governance for many years, finally stands up to carry out the principle of equality of shareholders, respect the autonomy, freedom, democracy and the rights of company and shareholders, reasonable define of 
boundary of the government regulation and enterprise autonomy, sharply reducing unnecessary intervention to the company from the executive power and national will, increasing the proportion of civil legal norms and facultative, expanding the autonomy space of the company, allowing the company's articles and agreement of shareholders making arrangements for company's internal matters in the principle of not be inconsistent with mandatory norms and the principle of honesty and credit ,which giving the full autonomy of state-owned enterprises.

There are two rules of capital: One is that it must flow to the place where can produce maximum profit, so the revised "company law" in 2005 cancelled investment restrictions"; The second is it must flow to the place where is more conducive to set up, so the revised "company law" in 2005 reduced the set up threshold of the company.

The "company law", revised in 2013 and effective as of March 1 in 2014 , further reducing the set up threshold of the company, relieving the financial burden of the investors, facilitating the company access, providing the legal safeguard of propelling the reform of company's registered capital registration system . In terms of universal significance for the company, state-owned company as an important part, the law has the following three modifications highlights: One is the company's registered capital has been changed from paid in system to subscribed capital system. The second is the cancellation of the minimum registered capital system. The third is the cancellation of proportion limit for the first time investment proportion and monetary investment.

As the modification and implementation of the "company law", for the reform of state-owned enterprises, the Chinese government is clearly put forward the reform direction of mixed ownership and the next step objective of the reform of state-owned enterprises is to make the marketization of state-owned enterprises.

To be specific, that means all the state-owned enterprises will be carry on reform of company system .Which means that most of the state-owned enterprises will be reformed and developed into equity diversified company besides minorities that related to national security, national defense and national economy. Basis on that, the "company law" will explore the perfection of the mechanism of state-owned property rights, equity transfer and develop the mixed ownership economy.

According to China's industrial economy yearbook and China's statistical yearbook, after the revised "company law" in 2015, the number of co., LTD. is increasing rapidly from 2456 in 2014 to 7192, the number of limited liability company is increasing rapidly from 6684 to 41972, and keeping the steady and fast growth in the later years, while state-owned enterprise is greatly reduced, Chinese state-owned enterprise co., LTD., and limited liability company which marked by corporate reform get great leap development .

\section{Since the 20 years of China's "company law" promulgated and implemented, China's state-owned enterprise still has practical significance of state-owned company characteristics.}

\section{The necessity of existence of China's state-owned enterprises}

The implementation of public ownership as the main body, diversified ownership economy mutual development as the basic economic system, which is the important pillar of the socialist system with Chinese characteristics.

Since promulgated and implemented of "company law" in 1994, state-owned enterprises of China has experienced 20 years' reform and development of company restructuring, out of restructuring, and the so-called " state-owned enterprises withdraw and private-owned enterprises enter " and "guo jin min tui". But, today, China's state-owned enterprises keeps the pattern of quantity decrease but the the total assets increase, occupying the leading role of the national economy.

According to Chinese financial yearbook data statistics, the number of China's state-owned enterprises keep decreasing year by year during the period of 1998 to 2008, but the trend is more and more slowly, especially after the financial crisis in 2008, Since 4 trillion investment from Chinese government has been put into the state-owned enterprises, the state-owned enterprises come back to the rising channel again in 2009.So as to say that the development history of the reform of Chinese state-owned enterprises has the distinct Chinese characteristics, the state-owned economy as the main 
body, the design of the rapid development of a variety of economic economic system is determined by China's fundamental political system, therefore, the China's state-owned enterprises has its real objective necessity in contemporary China.

\section{Overseas investment of China's state-owned enterprises overseas is presenting the momentum of rapid growth, but the investment proportion of the total overseas share is still small.}

After the $1990 \mathrm{~s}$, the whole world was affected by the heat wave of economic globalization. Economic ties between countries are more and more closely, many important changes occurred in the field of trade and investment. All countries can't get all the necessary resources, and will encounter problems of resource constraints, in order to meet the needs of domestic economic development, they need to get all sorts of production factors and natural resources from abroad. At the same time, each country output their relative abundant production factors and resources to other countries, so as to realize the reconfigure and the combination of the elements and resources between countries and get the relative and absolute interests.

Since the promulgation and implementation of the"company law" of China, especially after the accession to the WTO in 2001, both aspects of attracting foreign investment and overseas investment has been keeping the momentum of rapid growth, China has become a more and more active country in the field of global trade and a representative in emerging economies, China needs the world, the world also needs China.

After China's accomplishment of the task of San Francisco - Auckland new bay bridge, The U.S. side spoke highly that the bridge was the connection of two different countries and cultures between China and US. In the wave of global financial crisis in 2008, China's economic performance outshines others, China's state-owned enterprises maintained a steady growth, and China's economic role saves the world economy in some sense.

China's investment in Canada became active since 2009. On science and technology flied, Huawei and Canada's two major telecom operators, bell Canada, Telus worked together to build an innovation center .On financial field he industrial and commercial bank of China purchased a Canadian bank of east Asia, China and Canada reached \$32 billion bilateral swaps agreements in November 2014, Canada will build the first offshore RMB center in North America. China National Offshore Oil Corporation purchased Canada Nelson Company with full ownership by $\$ 15.1$ billion. The interactions of high-tech incubator project between Chinese with Canada is becoming more and more frequent and get a great result.

According to China business yearbook and China statistical yearbook, China's direct investment stock to Canada is \$103.29 million in 2005 and has grown to \$5.05072 billion in 2012 .

Visibly, economic globalization makes the economic interdependence of countries all over the world greatly enhanced both in breadth and in depth,

The participation of the increasingly stronger China's state-owned enterprises not only brings the capital to the host country , also brings China's own technology, equipment and talents, including China's unique Oriental culture, promote technological progress, products and structure upgrade, trade growth and employment growth for the host country, The final performance is to accelerate economic growth and political, cultural in-depth exchange of the host country ,which is a win-win growth pattern and also is the inevitable result of economic globalization.

According to the statistical yearbook data, China's foreign direct investment has entered into a rapid development period since 2005. China's foreign direct investment hit a high record of \$87.8 billion in 2012, growing 17.6\% from a year earlier, becoming the world's third for the first time . By the end of 2012, the cumulative net (stock) cash flow of China's foreign direct investment reached \$531.94 billion; ranking 13th in the world, preliminary established the international status of the big foreign direct investment. But the portion of China's foreign direct investment in the world is still limited, only $6.22 \%$ in 2013 , although grown rapidly, but it was worth only $10.2 \%$ of Stock of foreign investment in the United States, 29.4\% of the UK, 34.4\% in Germany, France's 35.5\%, 50.4\% in Japan. 


\section{China's state-owned enterprises take the profit motive as the leading indicator of the capital enterprise}

As a capital enterprise, pursuing maximum profits is the requirement of the capital. China's state-owned enterprises encountered the reform and development for 20 years since the "company law" enacted, its corporate characteristics of capital enterprise are increasingly clear, which means the basic motive of enterprises' existing is chasing profits and maximization of capital value. On that point, there is no fundamental difference under the capitalist system and the socialist system , the difference lies in that under the condition of the socialist system the proportion of state-owned capital is greater than the private capital, While it is just the opposite under the condition of capitalism .In the common sense of demutualization of capital enterprise, as a shareholder of state-owned capital and private capital, the rights and obligations of the capital is equal and neutral, of which has equal capital meaning. Even in western countries, many enterprises are controlled by the state capital. capital is not transfer, capital is not a gift, the capital is not helping poor, capital is to create profit, and capital is the motility of enterprises' survival and development. China's state-owned enterprises, as a common form of ownership in China, The Chinese government keep changing concept and innovating mechanism, dedicating to transform the state-owned assets to state-owned capital and transform assets management to the capital management, weakening government color and political complexion to the maximum limit, implementing demutualization management of State-owned enterprise, making state-owned capital going to the place where can get maximum benefit and profit according to the market rule, achieving the maximum value of the enterprise.

Therefore, there no need for overseas countries and groups to be political motivated on the overseas investment strategy of China's state-owned enterprises, pursuing the maximization of corporate profit and the value is also the main existence indicators of China's state-owned enterprises

\section{Corporate governance structure of Chinese state-owned enterprises is constantly getting perfect}

Compared with corporate governance structure of western developed country, the establishment of China's corporate governance structure experienced a different development history.

Revision of the "company law" in 2005 has further clarified the position of state-owned investors and the respective rights and responsibilities of corporate governance structure. Among them, a major breakthrough is that all the corporate must set up the board of directors no matter it is a wholly state-owned company, a joint stock limited company or limited liability company. Which has provide the legal basis for the perfection of corporate governance, reducing the administrative color of government direct intervention enterprise

In particular, after the "company law" enacted, modern enterprise system is different from the traditional system of state-owned enterprises and also different from transitional enterprise system formed since 1978 years since the reform and opening formed transitional enterprise system. This difference is not in form but actual, showing as: Firstly is to set up and improve the modern enterprise system, the state will undertake limited liability according to its capital contribution, enterprises govern the legal person property according to law; Secondly is to establish governance structure of interdependence and checks and balances within the enterprise which comprised by the shareholders, board of directors, board of supervisors, and managers; The third is that enterprise should take the production and business operation as the main responsibilities, having a clear profit target; The forth is that enterprises should be in accordance with the requirements of the market competition and form the efficient business organization and the perfect internal management system; The fifth is that all kinds of factors of enterprises production should have enough openness and liquidity, and realizing the efficient cooperation with the external capital market, managers market, labor market and market of other factors of production. 


\section{Conclusion}

In conclusion, in order to comply with urgent requirements of the deepening of economic globalization and transformation and upgrading of domestic economic development and arouse the initiative and creativity of China's state-owned enterprises to the upmost, the New Chinese government is committed to intensify efforts to promote the corporatization of state-owned Chinese companies and market-oriented reform, continuously push out measures such as reform of the mixed ownership system, trying to make state-owned enterprises become the truly main body of independent market competition as soon as possible, and become corporate enterprises that is bringing into the world unified measure index system. Therefore, overseas host nations and groups need to correctly understand substantive characteristics of China's state-owned enterprises and the strong impetus and huge potential of overseas' development, reduce the consideration and anxiety of political complexion, Using the global view and market-oriented method to attract and hug the Chinese state owned enterprises to take part in the cooperation and competition of the international market under the background of economic globalization and integration of world trade, active market forces of overseas investment around the world, so as to create a more competitive and more fairer way of cooperation and create a overseas investment market that full of harmony and competitive vitality.

\section{References}

[1] Chinese statistics yearbook. 2014

[2] China industrial economic statistical yearbook. 2012

[3] China's financial yearbook. 2013

[4] China business yearbook. 2013.

[5] International statistical yearbook. 2013 